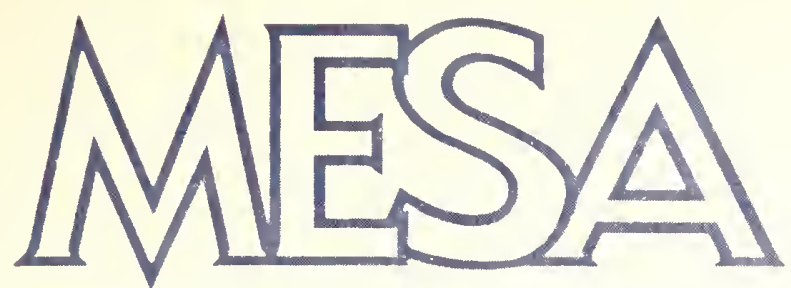

MARINE ECOSYSTEMS ANALYSIS PROGRAM

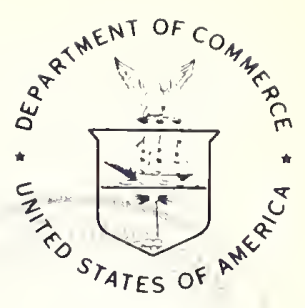

REPORT No. 74-3

and in

Sủmmary and Analysis

of Physical Oceanography Data

Collected in the New York Bight Apex

During 1969-70

R. L. CHARNELL

D. V. HANSEN 
MESA Report No. 74-3

\section{SUMMARY AND ANALYSIS \\ OF PHYSICAL OCEANOGRAPHY DATA \\ COLLECTED IN THE NEW YORK BIGHT APEX DURING 1969-70}
R. L. Charnell
D. V. Hansen

Marine Ecosystems Analysis Program Boulder, Colorado

August 1974

UHITED STATES

DEPARTMENT OF COMMERCE

Frederick B. Dent, Secrelary
NATIONAL OCEANIC AND ATMOSPHERIC ADMINISIRATION

Robert M. White, Admınıstrator
Environmental Research Laboratories

Wirmot $N$ Hess, Director

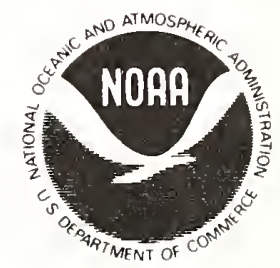

For sale by the Superintendent of Documents, U. S. Government Printing Office, Washington, D. C. 20402 


\section{DISCLAIMER}

The Environmental Research Laboratories do not approve, recommend, or endorse any proprietary product or proprietary material mentioned in this publication. No reference shall be made to the Environmental Research Laboratories, or to this publication furnished by the Environmental Research Laboratories, in any advertising or sales promotion which would indicate or imply that the Environmental Research Laboratories approve, recommend, or endorse any proprietary product or proprietary material mentioned herein, or which has as its purpose an intent to cause directly or indirectly the advertised product to be used or purchased because of this Environmental Research Laboratories publication. 
$\begin{array}{ll}\text { ABSTRACT } & 1\end{array}$

1. INTRODUCTION 2

2. TEMPERATURE AND SALINITY DATA 6

2.1 Apex Water Characteristics and Their Seasonal Variations 6

2.2 Hudson River Plume 11

3. LAGRANGIAN MEASUREMENTS USING SURFACE AND SEABED DRIFTERS 17

3.1 Near Bottom Transport 19

3.2 Surface Drifter Returns 25

3.3 Temporal Changes in Circulation 27

4. ADDITIONAL EVIDENCE OF CIRCULATION PATTERN 30

4.1 Direct Current Measurements 30

4.2 Density Distribution 32

4.3 Distribution of Deposited Organic Carbon on the Sea Floor

$\begin{array}{ll}\text { 5. SUMMARY } & 37\end{array}$

6. ACKNOWLEDGMENTS 39

7. REFERENCES 39

$\begin{array}{ll}\text { APPENDIX } & 42\end{array}$ 
Digitized by the Internet Archive in 2012 with funding from

LYRASIS Members and Sloan Foundation 
SUMMARY AND ANALYSIS OF PHYSICAL OCEANOGRAPHY

DATA COLLECTED IN THE NEW YORK BIGHT APEX

DURING 1969-70

R. L. Charnel1

D. V. Hansen

\section{ABSTRACT}

This report presents an analysis of physical oceanography data collected on a monthly basis in the apex of the New York Bight during 1969 and early 1970. Data include temperature and salinity values, recovery information on surface and seabed drifters, and current meter observations. Hudson River discharge and wind data from Ambrose light station are also included. The data show apex water to be stratified three-fourths of the year caused by high river runoff and insolation. During winter, heat loss and wind mixing destroy and impede reformation of stratification. There is a strong northward flow of water in the lower layers along the axis of the Hudson shelf channel; some of this bottom water flows into the Hudson estuary and part turns eastward to flow parallel to Long Island. Eventually, this eastward flow turns and joins the southwest flow of shelf water, suggesting that an anticyclonic circulation exists in the apex most of the year. Surface flow exhibits high seasonality in response to surface winds, with northward flow during spring and summer and southeast movement during fall and winter. Surface flow from Raritan Bay flows south along the New Jersey coast most of the year. 


\section{INTRODUCTION}

Increasing awareness of man's impact on water quality of the New York Bight has resulted in recognition of the need for detailed ecological studies of the nearshore zone into which vast quantities of municipal and industrial wastes are being dumped. Wastes from the metropolitán area have been dumped into apex waters informally since settlement and with government sanction since the turn of the century. Ecological awareness, plus increased load of waste dumping, dictates a detailed study of the apex system. In particular, an in-depth study of circulation which controls material transport is vitally important.

Few physical oceanographic studies of the New York Bight water have been made, and virtually none has focused on the nearshore zone. Bigelow (1933) and Bigelow and Sears (1935) assembled data for various seasons over several years which indicate that, in addition to fairly strong demarcation of shelf and slope water, apex water seems to differ in character from shelf waters during most of the year. However, temporal and structural resolutions, involving details of water characteristics near the New York Harbor mouth within the waste dumping area, are lacking.

The study of Ketchum et al. (1951), based on a year's worth of data, presented a fairly comprehensive discussion of the distribution of properties in apex waters. They were able to estimate some flushing rates for the area, but avoided comment on circulation patterns. They concluded that not more than 10 day's contribution of any pollutant, 
dissolved or suspended, would accumulate within the apex at any one time. More recent works by Bumpus (1965) and by Bumpus and Lauzier (1965) with seabed and surface drifters gave indication of seasonal flow structure in the bight and within the apex. On the open shelf, mean flow generally is to the southwest at both surface and bottom throughout most of the year. Near harbor mouths, such as New York and Delaware Bay, the bottom flow has a strong component into the estuary on the average. Spatial resolution on this scale is poor, and temporal variability is probably high.

In 1969, the U.S. Army Corps of Engineers provided support to the National Marine Fisheries Service Sandy Hook Laboratory at Highlands, N. J., to augment its continuing studies of the marine environmental features affecting distribution of marine organisms. These supplemental observations in the area from Jones Inlet, N. Y., to Monmouth Beach, N. J., were to provide details of nearshore water circulation as it relates to movement and dispersal of sewage sludge and dredging spoils deposited in the dump sites. Monthly observations made for 1 year under this program form the basis for one of the first detailed studies of physical oceanography in the apex. This report presents results of analysis of these data. The original data are on file at the Middle Atlantic Coastal Fisheries Center, National Marine Fisheries Service, Highlands, N. J.

For the Corps of Engineers study, a sampling grid of 23 stations was established in a part of the bight generally described as the apex. The station designations and pattern are shown in figure 1. Measurements 


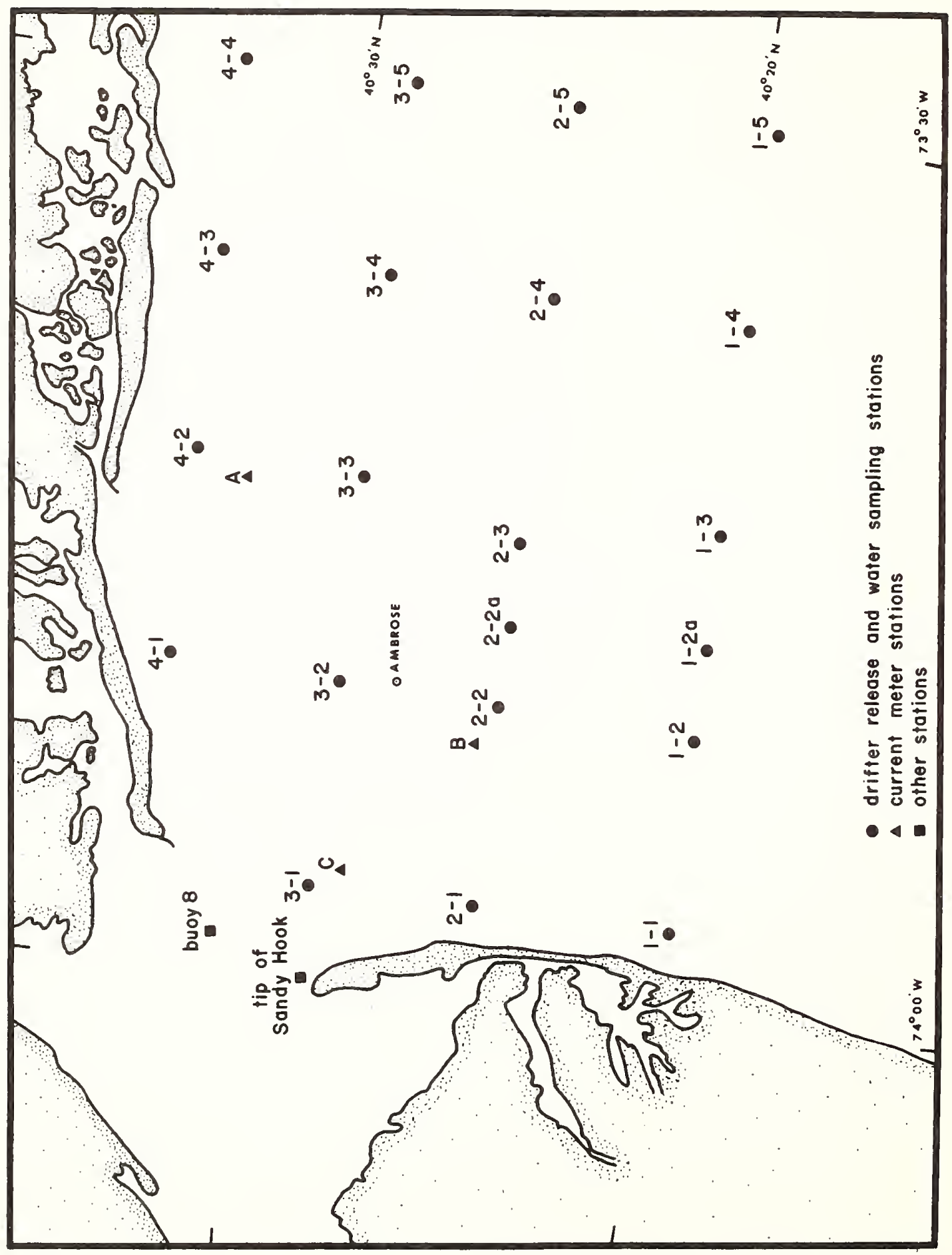

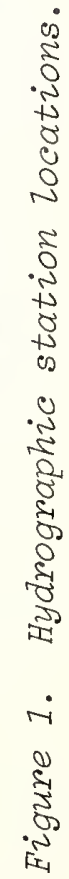


were made systematically at these stations to sample temperature and salinity at nominal depth intervals of $4 \mathrm{~m}$ and for dissolved oxygen near the bottom. Table $I$ is a calendar of these cruises, and the appendix has a description of instruments used for data collection.

Table I.

Calendar of Apex Cruises in 1969-70

\begin{tabular}{clcl}
\hline Cruise 非 & Date & Cruise \# & Date \\
\hline 1 & Jan. 31, 1969 & 8 & June 26, 27 \\
2 & Feb. 6, 7 & 9 & July 31, Aug. 1 \\
3 & Mar. 18, 19 & 10 & Aug. 18, 19 \\
4 & Apr. 8, 10 & 11 & Sept. 15, 16 \\
5 & Apr. 23, 24 & 12 & Nov. 3, 4 \\
6 & May 15, 16 & 13 & Dec. 18 \\
7 & June 5, 6 & 14 & Feb. 8, 1970 \\
\hline
\end{tabular}

In addition, several attempts at direct measurement of currents and particulate transports were made. Current meters were placed at four sites within the study area to measure current speed and direction near the bottom and at approximately $13 \mathrm{~m}$ above the bottom. These observations yielded four usable records from three of the stations (see fig. 1 for current meter station locations). Estimates of surface and bottom particulate transport were made with the use of seabed and surface drifters. These drifters were released at 21 of the fixed grid stations on each of the regular cruises. 


\section{TEMPERATURE AND SALINITY DATA}

Temperature and salinity data were collected on a nearly monthly basis from January 1969 through February 1970. Because cruises were generally of over 36-hr duration, data from these closely spaced stations were collected over several tidal cycles. This sample distribution, coupled with the semi-estuarine nature of the region, resulted in data sets with high spatial variability. For this analysis, these data are treated by groups rather than as maps or standard sections of properties to minimize biasing introduced by these variations.

\subsection{Apex Water Characteristics and Their Seasonal Variations}

Water in the bight apex is strongly influenced by runoff from the Hudson River and its tributaries that produces large salinity gradients. In the spring during high runoff, salinity values range from a low of about $18 \%$ o at the surface to $33 \%$ o at the bottom. Temperature is dominated by seasonal changes in insolation. Apex water reaches a seasonal high temperature of around $26^{\circ} \mathrm{C}$ in summer and a low of less than $2^{\circ} \mathrm{C}$ in winter.

During winter, river runoff is low and wind energy input is high, producing an apex water mass that is fairly well mixed and uniform in character. With onset of higher rainfall after March, apex water begins to stratify under the influence of a drop in surface salinity caused by increased river runoff. The early phase of this transition is illustrated with Cruise 4 data in the bottom panel of figure 2. This panel, like the two above it, is a composite temperature-salinity (T-S) diagram 


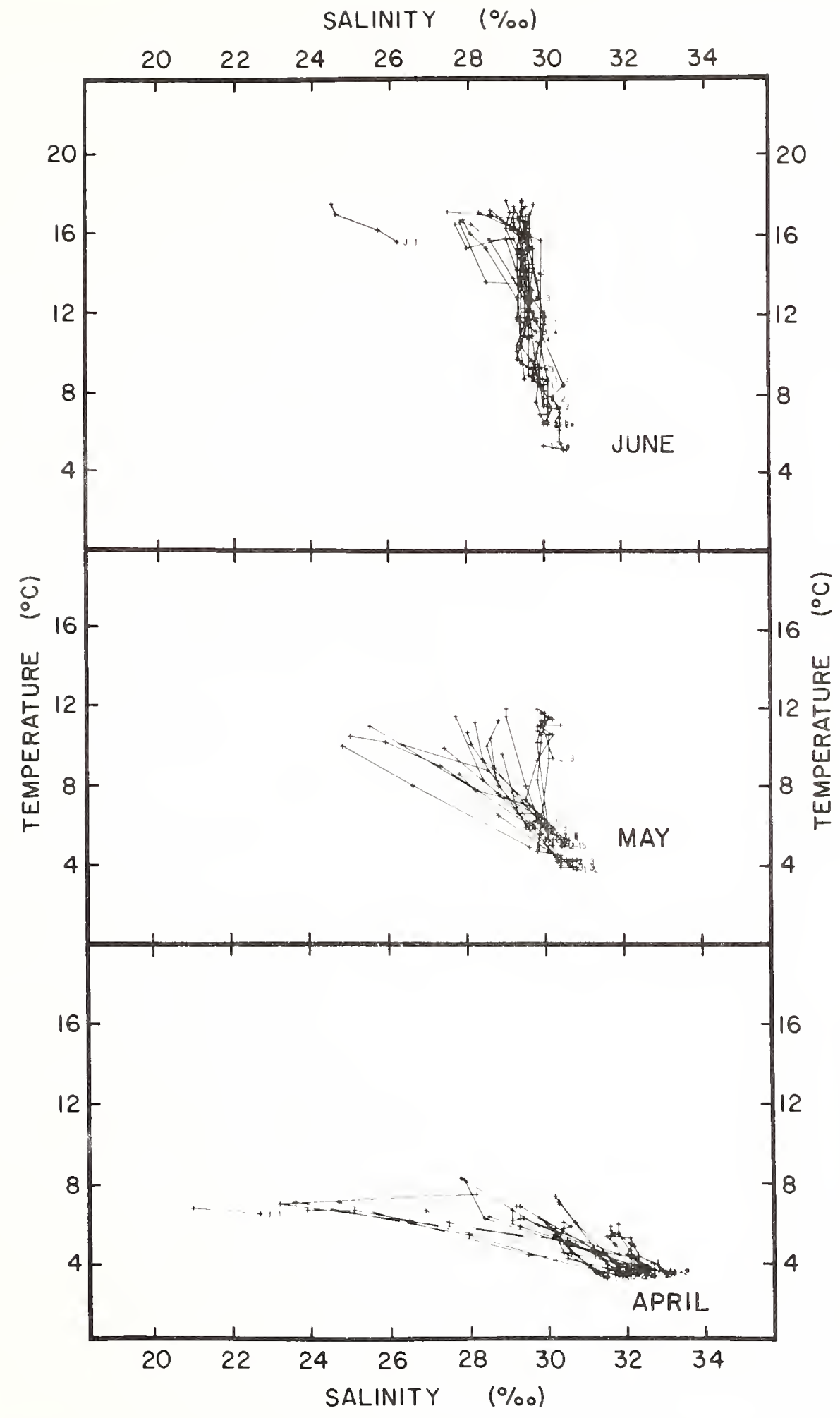

Figure 2. Temperature-salinity (T-S) data for every station during cmises from spring into summer of 1969. 
of data from every station for a single cruise. Individual stations are designated by numbers adjacent to the value taken at the greatest depth sampled.

Conditions of strong salinity stratification continue with little change during April. During May, runoff decreases and solar heating increases with the result that while stratification continues, its character shifts from being salinity-dominated to being temperature-dominated. This transition is illustrated by Cruise 6 data, summarized in the middle panel of figure 2 .

Transition from salinity stratification to temperature stratification is fairly rapid, apparently occurring within a month. Data from the June cruise show very little residual river influence. These data, summarized in the upper panel of figure 2, show only a narrow range of salinities. Data from the station closest to the harbor (非-1) and from some of those in that immediate vicinity show salinity values lower than characteristic of the rest of the apex water.

Temperature stratification increases through sumer and into fall. During August and September, surface water temperature reaches a high near $26^{\circ} \mathrm{C}$, while bottom water in the apex generally gets no warmer than approximately $12^{\circ} \mathrm{C}$. Bottom water temperature remains fairly constant throughout the period from June to October, caused by the inhibition of downward heat transfer.

Following the temperature maximum in August, surface water begins to cool at the rate of about $3^{\circ} \mathrm{C}$ per month. Stratification maintains a welldefined two-layer structure; after August, each layer becomes more 
homogeneous yet distinct from the other, caused by continued or increased mixing. Near the end of October, loss of heat from the surface layer brings its temperature to within a few degrees of that in the lower layer. Increased storm energy then results in a breakdown of stratification, and the entire water column becomes well mixed. At this time, there is relatively little salinity variation in the apex; except very near the harbor mouth, apex water becomes nearly homogeneous. This change in structure is shown by comparing the T-S structure in figure 2 to structure shown by the T-S data in figure 3. The three distinct groups of curves in figure 3 represent data from the November, December, and February cruises.

The upper data group in figure 3 was collected on November 3-4. With the exception of stations along the New Jersey coast (非-1, 非-1, and \#1-1), data from all stations show a salinity range of only $2 \%$ o and a temperature range of about $2^{\circ} \mathrm{C}$. The middle group of data, collected December 18, show similar low ranges in temperature and salinity. Mean salinity has increased by about $2 \%$ while the mean temperature decreased by over $7^{\circ} \mathrm{C}$ during the previous 44 days. The February 8,1970 , cruise, depicted by the bottom group of curves, shows little mean salinity change, but a further drop of about $4^{\circ} \mathrm{C}$ in mean temperature. Data from Cruise 1 , collected a year earlier, show a similar pattern.

A rapid breakdown in stratification occurs during October. Following this change to near-homogeneous conditions, there is a rapid drop in temperature of apex water. From November 3 to December 18, there is a $7^{\circ} \mathrm{C}$ drop in temperature that represents a heat loss of about $1.4 \times 10^{4} \mathrm{cal} / \mathrm{cm}^{2} / 44$ days 


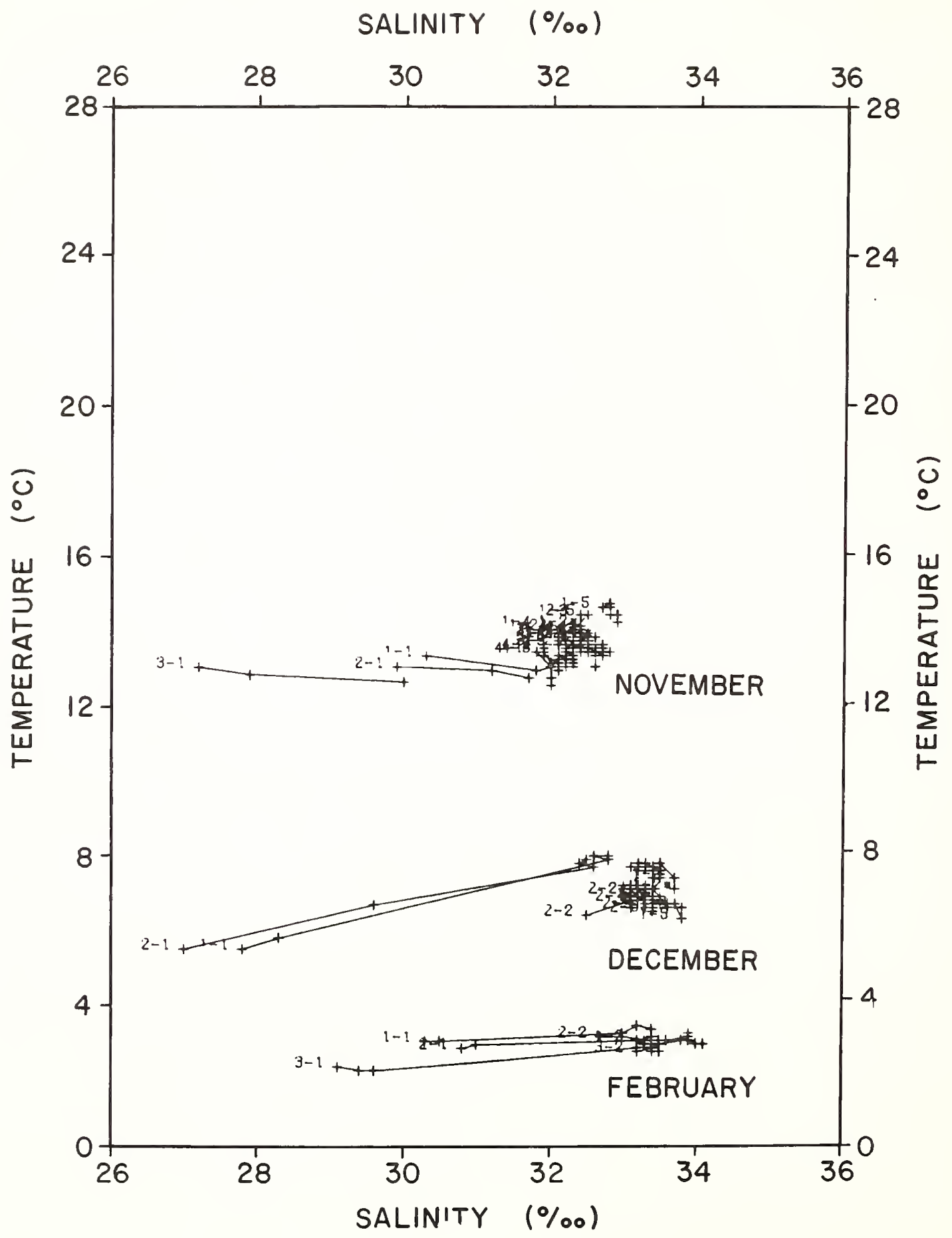

Figure 3. Temperature-salinity (T-S) data for every station during cruises from fall into winter of 1969-70. 
Although this heat loss is high, it is consistent with estimates of normal heat flux through the sea surface.

\section{2 Hudson River Plume}

The plume of Raritan Bay effluent, the so-called Hudson River plume, is a dominant feature of the apex for nearly 9 months of the year. Even during winter when apex water is fairly uniformly mixed, several of the stations near New York Harbor show substantially lower salinities under influence of the plume (cf., fig. 3). The plume is most well-developed following the spring runoff increase. Plume growth is greatest in the April-May period. Figure 4 is a plot of surface salinity for that period. The data, collected April 23-24, clearly show the plume depicted by a marked decrease in salinity. Near the bay mouth, salinity is more than $10 \%$, less than that of ambient apex water.

The plume apparently lies against the New Jersey coast rather than flowing to the east or southeast into open water of the apex. For all cruises of 1969 where data are sufficient to define a low salinity plume, the feature is located adjacent to the New Jersey shore. In fact, subsequent satellite data (Charne11 et a1., 1974) suggest that this is the preferred location of the plume all year long. This tendency for the plume to follow the New Jersey coast may be explained as quasi-geostropic flow of the riverine input or may simply reflect advection of the low salinity water by general coastal circulation.

This preferred location can be shown in another way with the aid of time history profiles. Figure 5 shows time history profiles of tempera- 


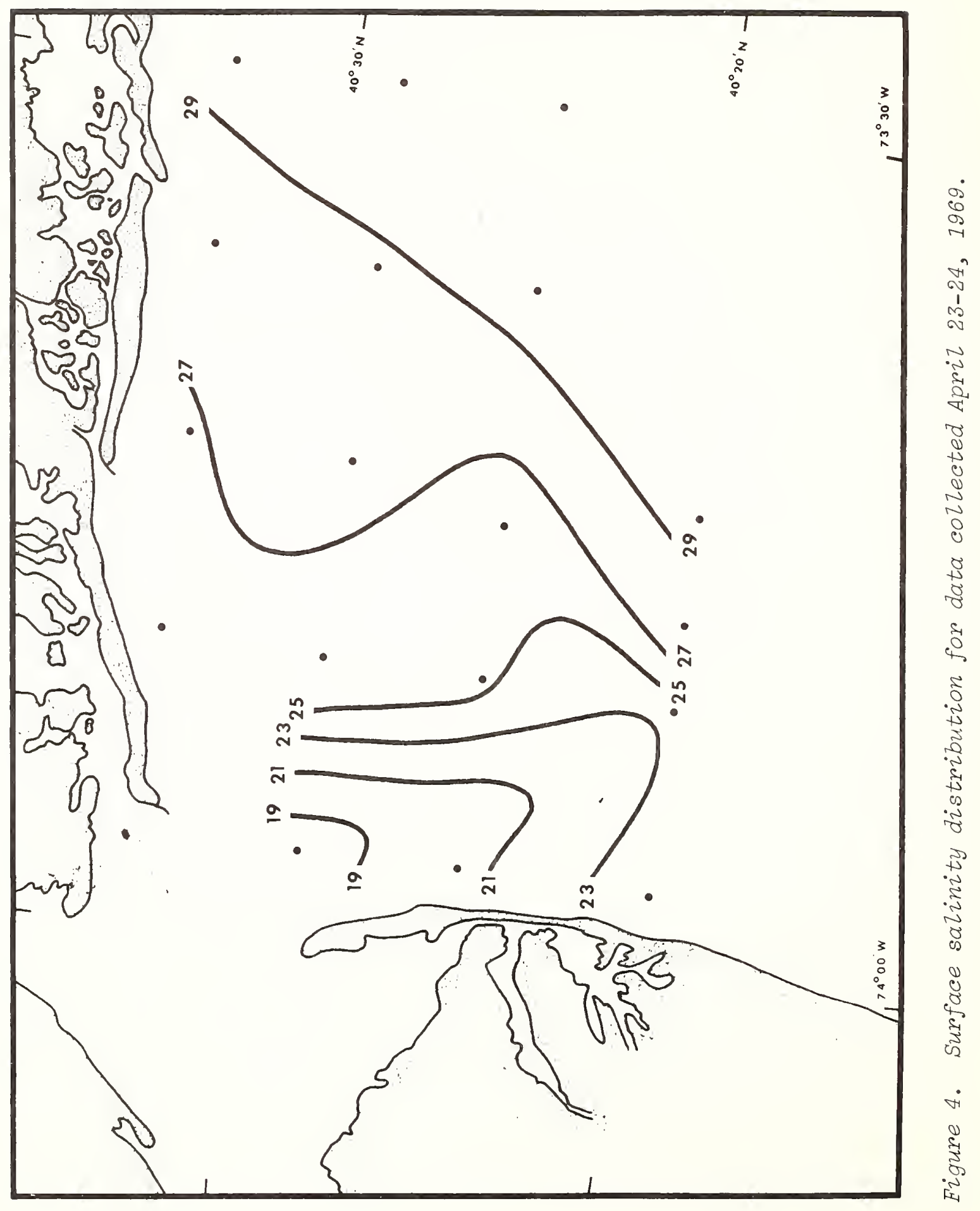



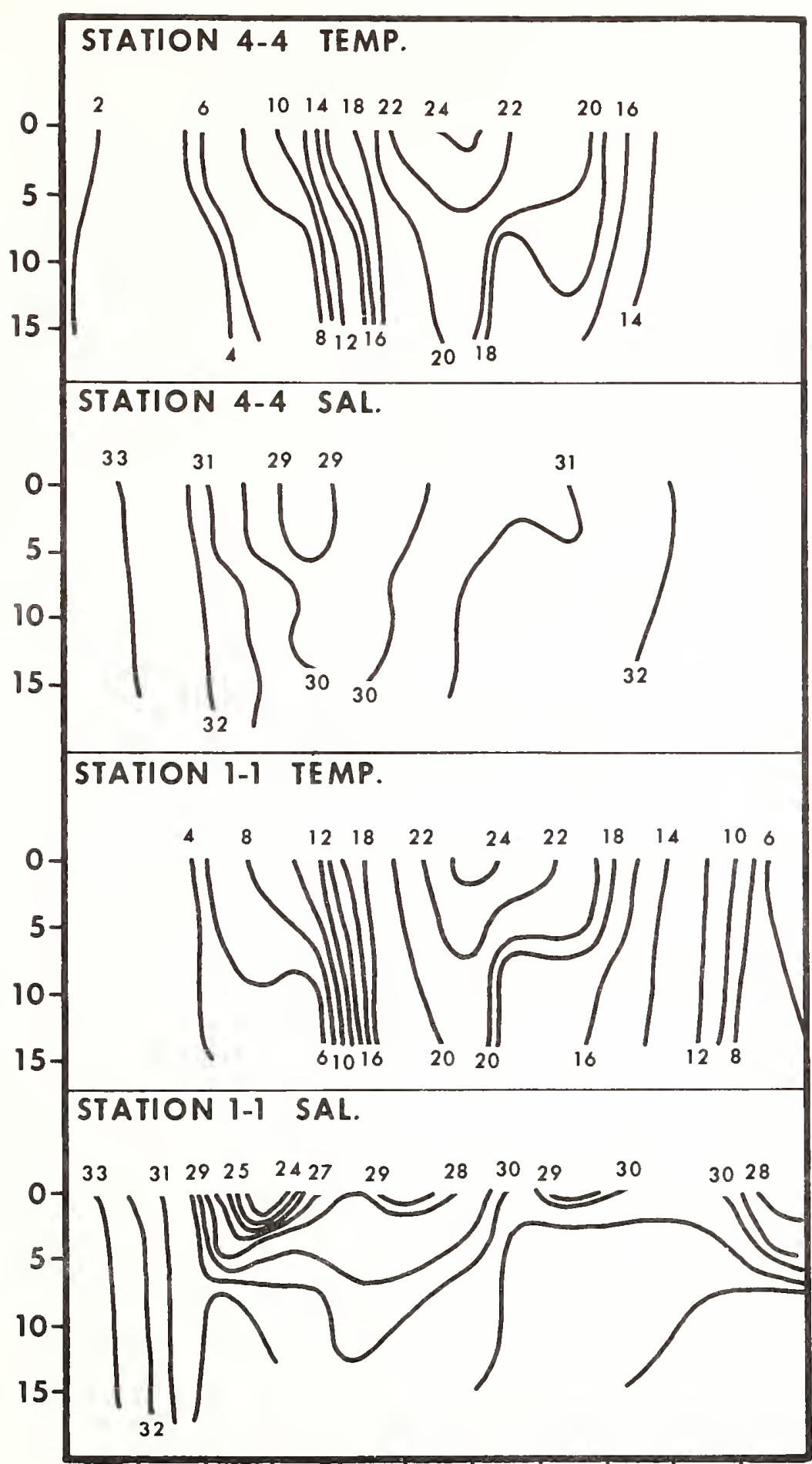

FEB TMAR APR TAYTJUNE JULY TAUG SEPT TOCT NOVI DEC

1969

Eigure 5. Time history profizes of temperature and salinity for stations 1-1 (New Jersey coast) and 4-4 (Long Island coast). 
ture and salinity for a station near the New Jersey shore (非-1) and for one near the Long Island shore (非-4). Station 1-1 shows a marked drop in surface salinity as river-controlled stratification begins in late March. Through April and May, surface salinity continues to drop substantially. A minimum value of less than $24 \%$ is reached some time in early May. Data from this station clearly show the effect of the Hudson plume.

Data for station 4-4 do not show the same influence from river runoff; during the season of maximum runoff, water along Long Island shows only weak salinity stratification. A minimum in surface salinity occurs from mid to late May, several weeks after the comparable minimum at station 1-1. The minimum at station $4-4$ occurs at a time of general salinity reduction in all apex water affected by mixing and horizontal distribution of the relatively "fresh" water of the Hudson plume and of other sources along the coast. In general, stations east of the Hudson shelf channel exhibit behavior much like that of station 4-4; all stations west of the channel reflect the character of station 1-1.

Effect of river runoff on apex water can be shown with a comparison of streamflow to surface salinity at selected stations. Figure 6 is a composite time-history plot, showing streamflow and surface salinity at both Ambrose light station and at station 3-1. Streamflow for the Hudson River is gaged at Green Island, a point substantially upstream from Raritan Bay (Water Resources Division, 1970, 1971). Because the Hudson represents about 90 percent of the freshwater supplied to the Raritan Bay system and the Green Island station gages a relative measure of 


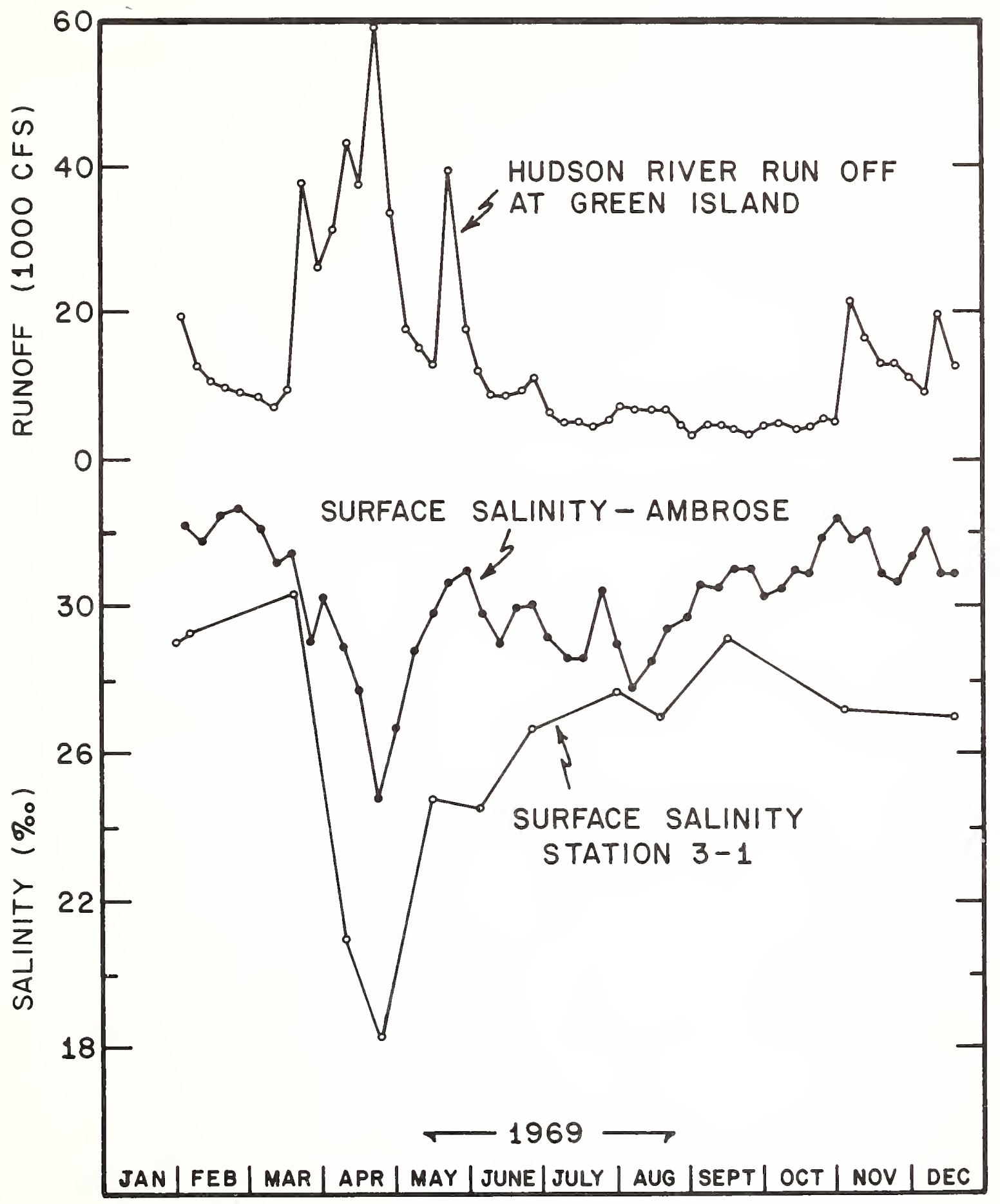

Figure 6. Comparison of time history plots of Hudson River moff to salinity at station 3-1 and the Ambrose light station. 
Hudson flow, then riverflow measured at Green Island should accurately represent relative input of freshwater to the apex. The Ambrose station (data from Chase, 1971) lies to the east of station 3-1 and, because the Hudson plume preferentially exists in the western portion of the apex, that station should and does show less influence of the Hudson and hence has generally higher salinities than station $3-1$.

Maximum riverflow in late April is reflected by a substantial drop in surface salinity at both apex stations. A secondary peak in riverflow in late May shows a similar, but not as strong, decrease in surface salinity. As riverflow drops with onset of summer, surface salinities generally stabilize, and values at the two stations approach one another with the station $3-1$ values coming to within $1 \%$ of the Ambrose values. A runoff increase that occurs in November is reflected by a drop in surface salinity at station $3-1$, but shows no similar influence at Ambrose. This difference probably results from the plume lying even closer to the New Jersey coast than usual and not penetrating as far east as Ambrose. Additionally, since this is a period of high wind mixing, the plume may have been completely mixed with ambient water and obliterated before it had much opportunity to penetrate far into the apex.

The river plume lying along the New Jersey coast leads to a demarcation of water types even within such a small area as the apex. The boundary between water types tends to be a north-south line that coincides with the axis of the main topographic feature of the apex, the Hudson shelf channel. East of the boundary, water is generally of shelf influence and hence more oceanic in character. Water there tends to show less salinity stratification. 
Figure 7 shows a comparison of T-S cycles for stations representing each of these two water types. The left-hand section of the figure shows T-S data for station 2-I, representing the area west of the boundary; the right-hand section shows data for a station east of the boundary (非2-4). Each pair of curves includes the time history of surface values (solid line) and of near bottom values (dashed line). Numerals along the curves depict cruise numbers. There is strong riverine influence on salinity structure for the coastal water, with even the bottom water showing large changes in salinity. Data from the shelf water station show both less annual range and less vertical salinity structure. The zone paralleling the Hudson shelf channel apparently exerts a strong barrier influence; apex stations to the east exhibit characteristics similar to station 2-4, while those to the west are similar to station $2-1$.

\section{LAGRANGIAN MEASUREMENTS USING SURFACE AND SEABED DRIFTERS}

Sma11 drifters designed to measure direction of water movement at the surface and bottom of the water column were used for this study. Reaction of these drifters to water movement closely approximates that of other small movable objects at the surface and near the seabed. Their behavior thus provides an estimate of the effect of water movement on transport and dispersal of sewage sludge and dredging spoils. The seabed drifter is a positively buoyant plastic saucer (diameter $19 \mathrm{~cm}$ ) fastened to a small-diameter stem, $54 \mathrm{~cm}$ long. The free end of this stem is weighted so that the whole drifter has slight negative buoyancy. 


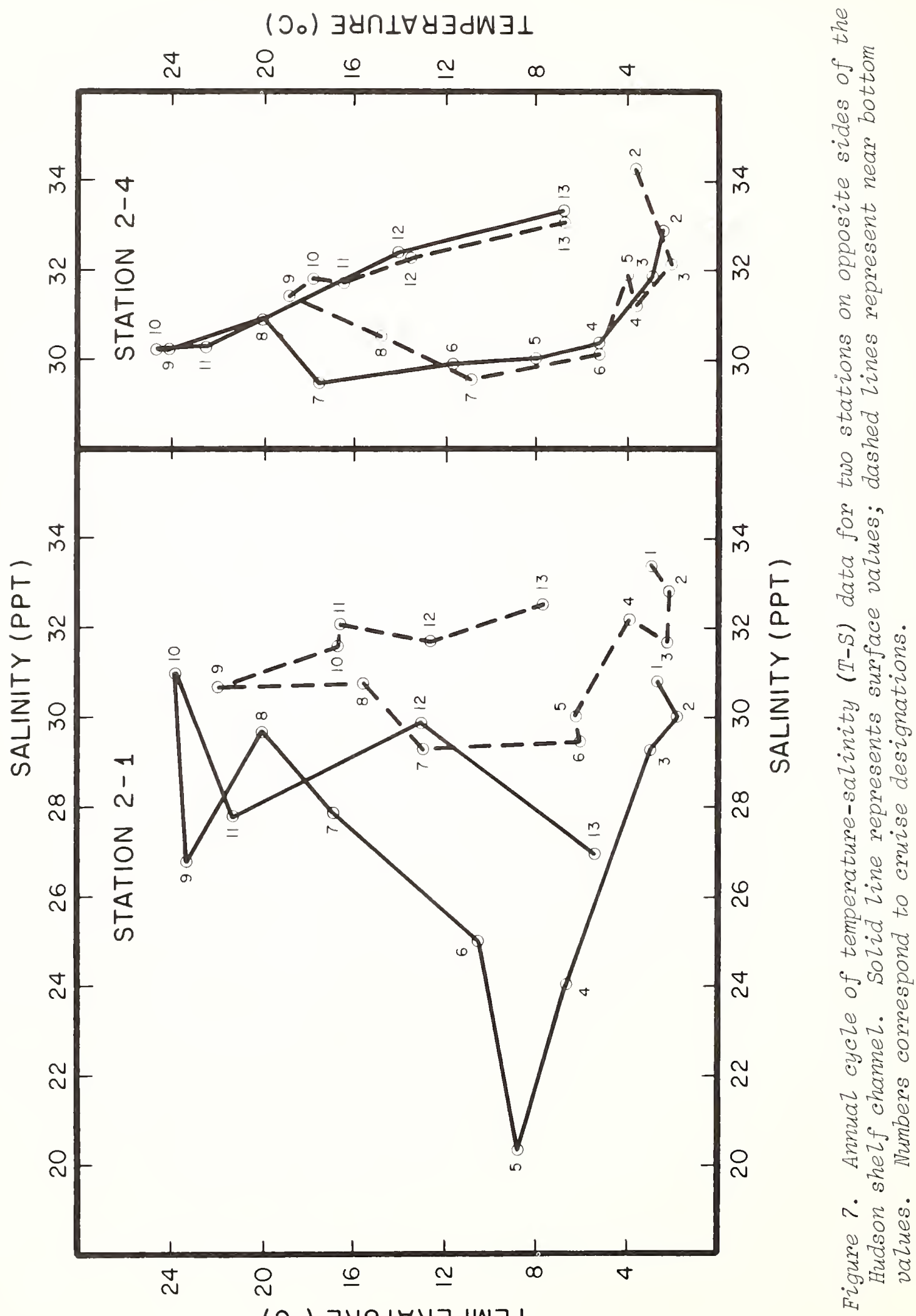


Surface drifters used in the study were small bottles, ballasted to float vertically and yet present a low above-surface profile to minimize unwanted wind effects. Details of construction and operation of these drifters can be found in Bumpus (1965) or Harrison et al. (1967).

A study of this sort relies on the public to return information on the time and location of recovery for each drifter found. Positive results are obtained only when drifters move into areas accessible to the public. This may be an important consideration in an area like New York Harbor where there are limited areas for drifters to wash up on a beach.

Of the 1,886 surface drifters released in 1969, 497 or about 26 percent were returned. Of the 2,190 seabed drifters released in $1 \dot{9} 69,710$ or about 32 percent were recovered. These rates of return are exceptionally high for this type of investigation and are attributable to a combination of vigorous onshore transport mechanisms and the intensity of traffic on adjacent beaches. Results of the analysis reported here are based primarily on spatial and temporal patterns determined by returns of those drifters released during 1969.

\subsection{Near Bottom Transport}

Several studies using seabed drifters have been made on the continental shelf in the Middle Atlantic Bight area. The study by Bumpus (1965) indicated that for nearshore, the tendency is for westerly or southerly flow with a component toward the coast; however, the onshoreoffshore component is difficult to distinguish from more or less isotropic dispersion because only those drifters carried onshore yield any infor- 
mation. Bumpus' study, like that of Harrison et al. (1967), indicated that there is definite residual bottom drift toward the mouths of estuaries. Such flow into estuary mouths is expected as a normal consequence of estuarine circulation driven by freshwater outflow and has been observed in a wide variety of situations (Conomos, et al., 1970; Gross et a1., 1969).

Data from the present study also show the pattern described by Bumpus. Circulation detail is, however, largely masked by greater variability. Overall patterns are more easily seen if the returns are presented in relation to their point of origin. For example, figure 8 shows the percentage return of drifters released from each station during the entire year. Values for individual stations are contoured to provide a visual impression of the pattern of returns. As might be anticipated from simple dispersion considerations, areas closer to land have a higher percentage return. A significant feature of these data is that minimum percentage return occurs along the axis of the Ambrose channe1-Hudson shelf channel rather than from the station farthest from shore. This might imply that drifters placed in this area are moved rapidly seaward and are lost or that this area is a "dead area" of 1ittle motion. Neither of these views is consistent with the interpretation by Bumpus or the principles of estuarine circulation.

It appears more likely that drifters from this region are preferentially drawn into the New York-Hudson River estuarine system. Stewart (1958) showed that upstream flow of bottom water occurs in at least the lower $50 \mathrm{mi}$ of the Hudson River estuary. This phenomenon probably wil1 have a seaward continuation. 


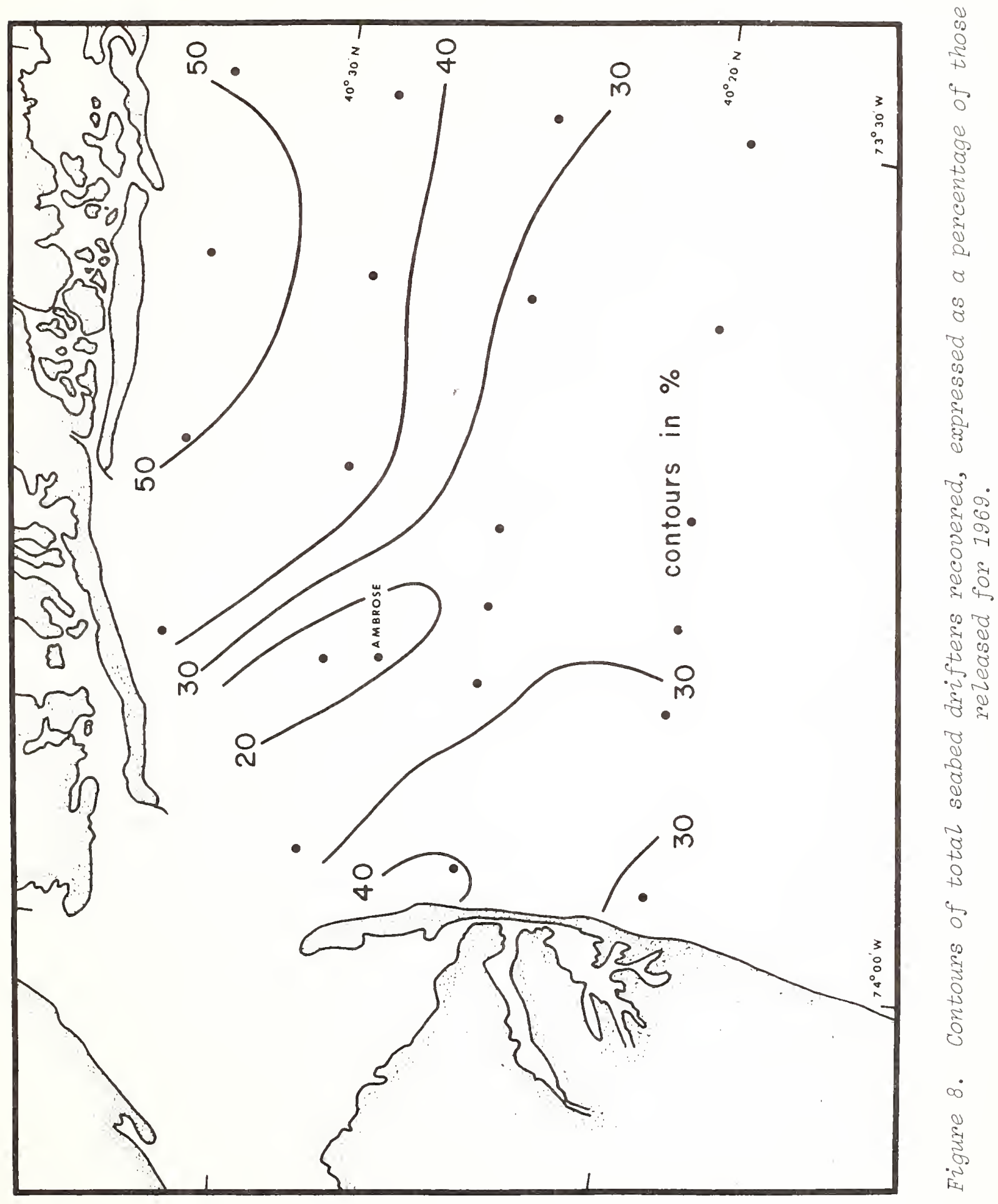


Examination of a chart of the Upper Bay and Hudson River north of the Narrows suggests few areas that are suitable for beaching of these drifters. If not beached, in time they will become covered with marine growth and will deteriorate. It is quite probable that the low return rate near Ambrose reflects upchannel migration and subsequent loss to the investigation rather than a seaward flushing of the drifters.

This view is also consistent with the fact that there are higher return rates from stations farther out to sea. A drifter moving along the bottom is subjected to two processes--advection and dispersion. Advection is affected by the organized flow into the estuary, while dispersion is induced by tidal flow and other oscillations. Drifters deployed farther from the harbor entrance are more likely to be dispersed out of the organized flow and to be beached before going through the bay mouth.

The hypothesized flow into the estuary may be tested by identifying the origin of all drifters found somewhere within the New York Harbor system. Eighty-one drifters, or 3.7 percent of all those released, were found within the bay. Greater sensitivity to origin is obtained by relating bay recoveries to total returns from a single station rather than to total releases (fig. 9, upper panel). For these data, highest relative rates of return are found at stations closer to the mouth than for those stations farther out. The axis of maximum relative return corresponds in a general sense to the Hudson-Ambrose channel.

Drifters were found predominantly in two areas: 477 drifters were recovered along the south coast of Long Island while 127 drifters 

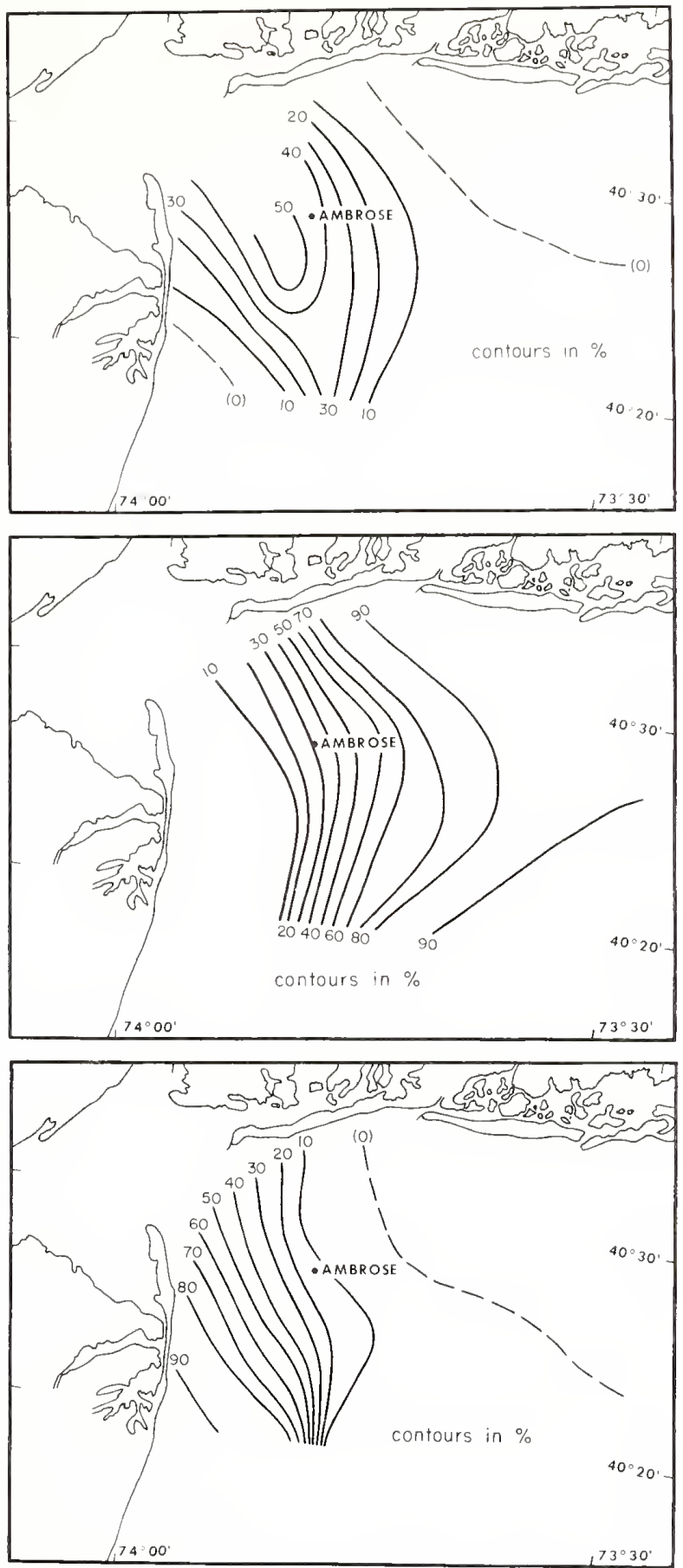

Figure 9. Origin of seabed drifters by recovery locations. Contours of total seabed drifters recovered, expressed as a percentage of those released at individual stations: upper panel, recoveries in Hudson estuary; middle panel, recoveries on the Long Island coast; and lower panel, recoveries on the New Jersey coast. 
beached along the eastern coast of the mainland from Sandy Hook to Cape May, N. J. The remaining 35 drifters were found at miscellaneous 1ocations not germane to the study area and have not been included in our analysis. For comparison to estuary returns, origin data for drifters recovered in the two predominant areas are presented in the lower two panels of figure 9. For the mainland recoveries (fig. 9, bottom pane1), return is clearly dependent upon distance from shore. Orientation of contours generally follows the axis of hypothesized bottom flow into the estuary. A significant feature of this distribution is that almost no drifters released in the northeast section of the grid moved southwest onto the New Jersey coast.

Returns of drifters beached on Long Island also show a dependence on distance from shore (fig. 9, middle panel). Drifters appear to be carried ashore here more frequently from a large part of the sampling grid. Contours for these data also are generally parallel to the axis of hypothesized flow into the estuary in the western portion of the sampling grid. Returns are high from the south central portion of the grid and from the northeast section of the grid. The general impression conveyed by a year of bottom drifter data is of a general clockwise circulation in the bight upon which is superimposed an estuarine circulation into the estuary and dispersion by tidal and wind-driven currents. This picture is consistent with the circulation pattern described by both Bumpus (1965) and Bumpus (1973) using drifter data. 


\subsection{Surface Drifter Returns}

Surface drifter return data can be used to infer surface circulation in the bight apex. There is somewhat more seasonal variability in these data resulting from wind effects. As might be expected, there was almost no evidence that surface drifters went upstream into the bay; only one drifter was found in this area.

Data on the origin of recovered surface drifters are presented in the upper panel of figure 10. It is evident that drifters released closest to the south shore of Long Island had the greatest incidence of recovery ashore. For a clearer picture of drifter migration, the data can be grouped by Long Island or New Jersey recovery as was done for the seabed drifters. Origin of release for the 406 drifters collected on the south shore of Long Island is shown in the middle panel of figure 10. Again, recoveries on Long Island are normalized by total recoveries. There appears to be a central ridge of high return with areas of low return on either side. During most of the year, winds from the south and west predominated. Winds from these points moved the drifters to the north and tended to ground them on Long Island.

The area of low return to the west can be accounted for by the shift in recovery to the east coast mainland. Origin of release for these 37 recoveries is summarized in the bottom panel of figure 10. The data show two features: overall low return to the mainland, and a very small area from which drifters are likely to beach on the mainland. These two diagrams clearly indicate, at least for 1969, that the predominant character of surface flow was a tendency for floating material to move in a northward direction. The 53 drifters not accounted for in these return 

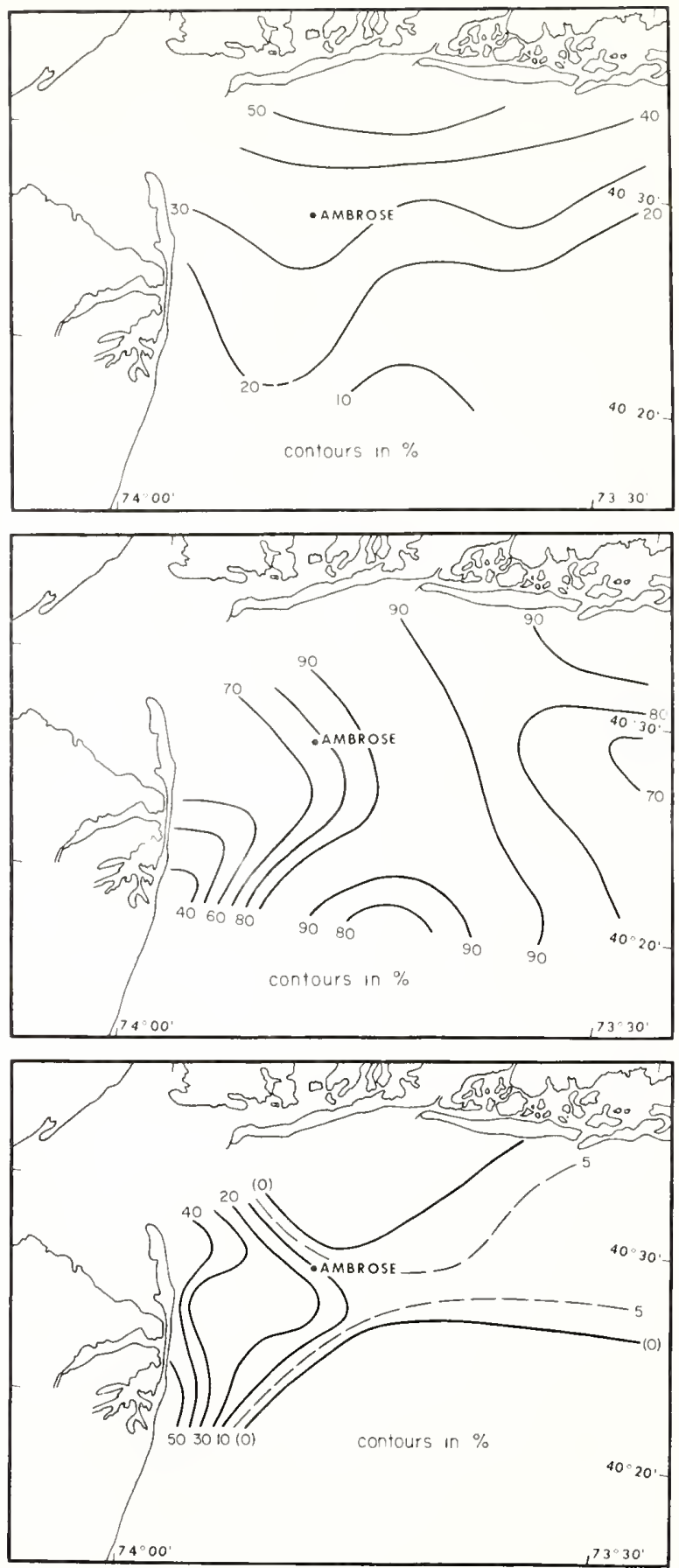

Figure 10. Origin of surface drifter recoveries. Contours of total surface drifters recovered, expressed as a percentage of those released at individual stations: upper panel, total recoveries; middle panel, recoveries on the Long Island coast; and lower panel, recoveries on the New Jersey coast. 
areas were found in miscellaneous locations not germane to the study area and have not been included in our analysis.

\subsection{Temporal Changes in Circulation}

It might be thought useful to examine the time-dependent aspects of both surface and near bottom flow by interpreting data from the individual cruises. This type of analysis, however, would require release of substantially more drifters each month than were used for this study. Because of the stochastic nature of the processes controlling drifter movement, small numbers of returns from releases are not significant. Another problem is indicated by the low recovery rate for upchannel seabed drifter migrations. Ordinarily at a given station, direction of drift is inferred from all returns for releases at one time; if a substantial number of drifters is not found (as is clearly the case for those that are carried offshore and is believed to be the case for those carried into the estuary), their direction is not represented and resultant flow estimates are biased.

One means for delineating temporal aspects of the circulation is to examine the total rate of return from all stations as a function of time, as is depicted in figure 11. The middle panel of figure 11 indicates return of surface drifters while the bottom panel indicates return of seabed drifters. Dots for each curve represent the time the drifters were released; on the average, most were recovered during the following month. The upper panel of the figure shows the time history of weekly mean wind vectors as measured at the Ambrose light station. Winds show a dramatic shift in mean direction from northerly to southerly from March to April. 


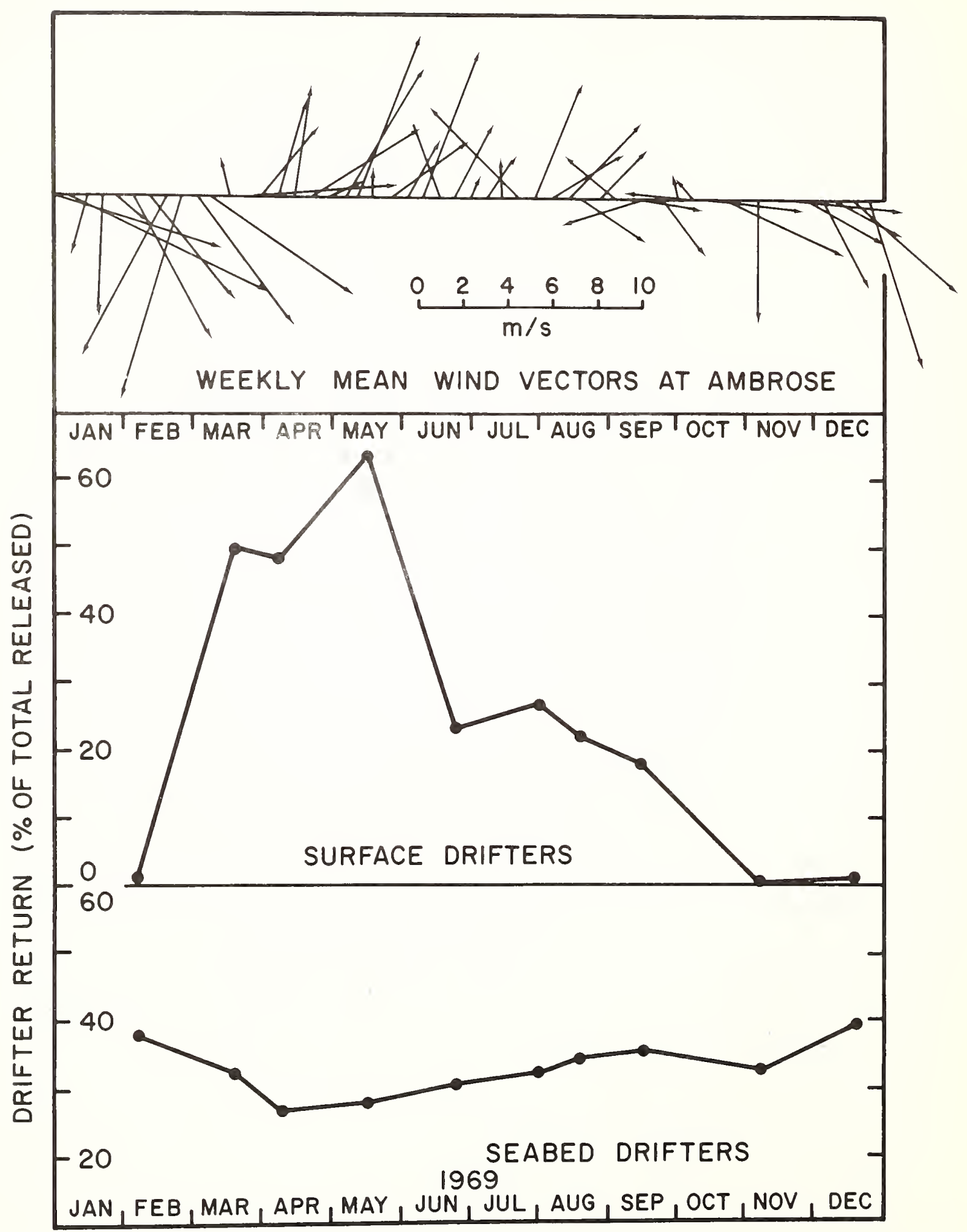

Figure 11. Time history of drifter retums compared to winds at Ambrose light station. 
Winds continue to be from the south and weaker till near the end of September when another shift to northerlies occurs.

It is apparent from the surface drifter returns that wind-induced effects tend to dominate surface circulation. In the early part of the year when winds are from the north-northwest, virtually no surface drifters are recovered; presumably they are swept out to sea. Similarly, during spring and summer, winds push surface water and hence drifters onto the Long Island beaches. Then into late summer and fall, recoveries decrease as the winds become variable and then switch to the southeast. It is not likely that decreased beach traffic in winter months accounts for diminished returns of surface drifters because returns of bottom drifters have a slight maximum for this period. In general, however, return of seabed drifters showed little seasonality. There was a slight decrease during the period of high surface return. This suggests that during the spring, when outflow at the surface is strongest, more seabed drifters return up the Hudson and hence are lost. Actual estuary recoveries of the seabed drifters do show a slightly different picture. For just 2 months, August and September, recoveries were much higher than for any other period; there were 17 and 20 returns, respectively. This is nearly three times the recovery rate for the more nearly average months of April and May that had recoveries of five and eight drifters, respectively 


\section{ADDITIONAL EVIDENCE OF CIRCULATION PATTERN}

There are several other data sources that tend to confirm the circulation picture inferred from drifters. These data include the incomplete current meter records, density data, and distribution of dumpsite organic carbon deposited on the sea floor.

\subsection{Direct Current Measurements}

Evidence for the bottom circulation pattern also includes direct current measurements made during the study. While the records are few, nonsynoptic, and for only short periods, they do provide evidence for bottom water movement similar to that inferred from bottom drifter returns.

All current meters set out for this study rapidly developed marine growth that interferred with their operation. For the four reliable records, at least 2 weeks of observations can be considered valid. These four records were taken at three stations: (a) near bottom and mid-depth observation in late June, $3.5 \mathrm{mi}$ south of Atlantic Beach, N. Y. (station A); (b) near bottom observations in late February, $2.5 \mathrm{mi}$ southwest of Ambrose (station B); and (c) near bottom observations in late Mayearly June, $3.5 \mathrm{mi}$ east of Sandy Hook (station C). Locations of these stations are indicated on figure 1. A summary of these measurements is presented in figure 12; for each station, the progressive vector diagram is presented for the valid segment of each record.

The southernmost station $B$ is not in an area that, on the basis of drifter data, is in the main zone of upchannel return flow. Wind during this period was predominantly from the west. The record for station B 


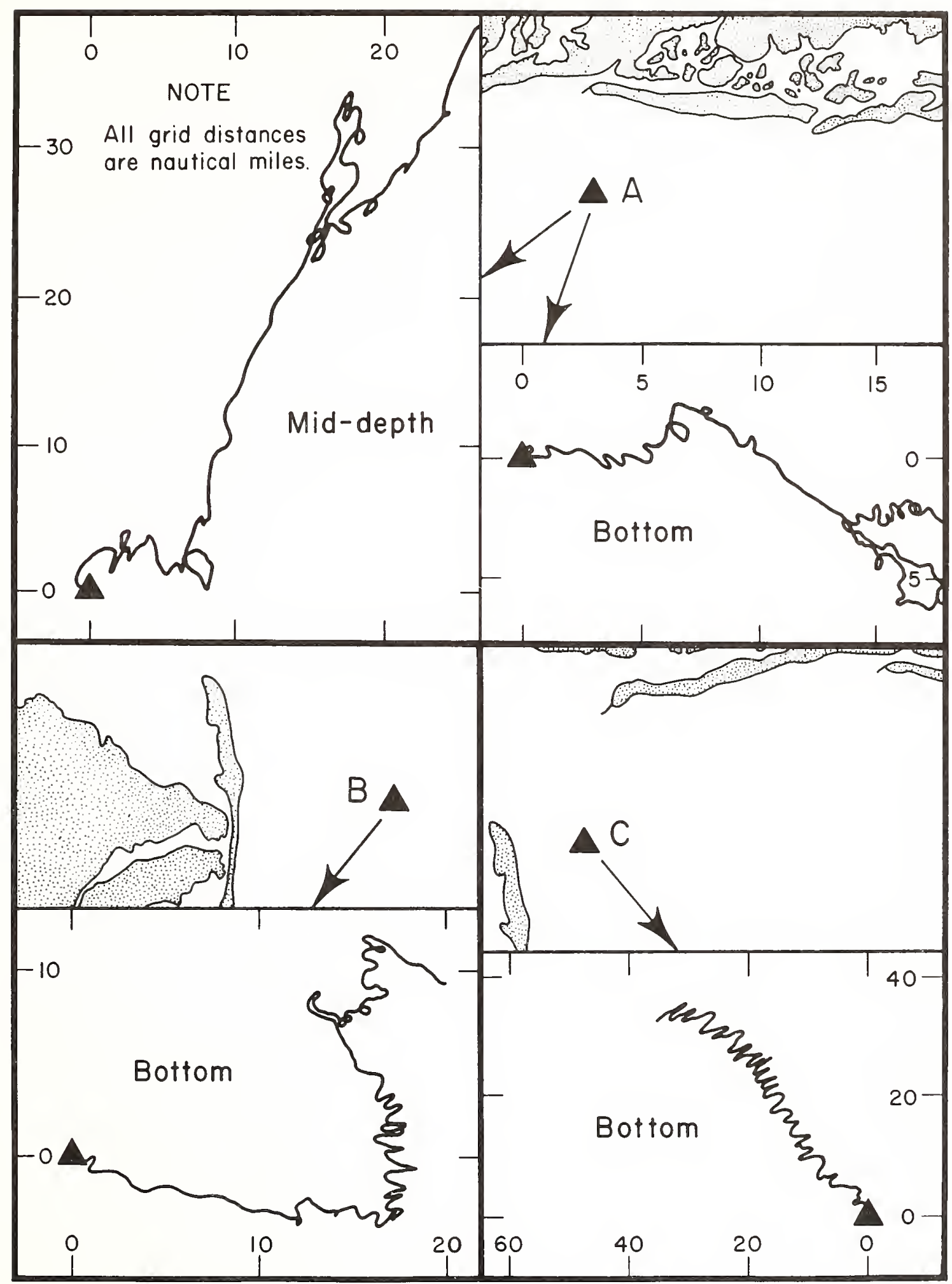

Eigure 12. Progressive vector representation of current meter data from current meter stations $A, B$, and $C$. 
in February shows flow generally eastward away from the coast for the first 4 days; subsequently, net drift was toward the north until the record becomes invalid. Average net drift for the entire period was $3.9 \mathrm{mi} /$ day toward the east-northeast.

Station A is situated in an area which, based on seabed drifter analysis, is expected to have bottom flow predominantly to the west. For this period, local winds were variable but generally from the south. The current records show that flow tended to follow bottom contours away from the estuary mouth in a generally eastward direction, both near bottom and at mid-depth. After about 1 week, net flow at mid-depth swung northeast toward the shore while net bottom drift shifted to the southeast away from shore. Average net drift was $3.3 \mathrm{mi} /$ day toward the northnortheast at mid-depth and $1.9 \mathrm{mi} /$ day toward the east at the bottom.

Station $\mathrm{C}$ was situated almost in the path of inferred bottom flow into the estuary mouth. Here, bottom water would be expected to flow northwest into the bay. This, in fact, is what the current record shows for late May and early June. There was substantial tidal oscillation, but net drift followed a heading of about $320^{\circ}$ true. Average net drift over the period was $4.2 \mathrm{mi} / \mathrm{day}$.

\subsection{Density Distribution}

Temperature and salinity values from this area also suggest an estuarine circulation pattern and/or general clockwise circulation in the bight. Data from the four stations that were most nearly alined to the Ambrose-Hudson channel can be used as a section along the most likely axis of flow. Bathymetry tends to confine flow along the axis, and 
tidal currents tend to conform to this axis. Even though the study area is an open ocean segment, there are bounds on the system that suggest estuarine behavior. Figure 13 presents a vertical section of density upon this axis about the time that current station $\mathrm{C}$ was occupied. The data clearly suggest a pattern characteristically found in estuaries. The pitfalls of attempting to infer circulation from temperature and salinity distributions in estuaries and in coastal areas are legion, but landward flow near the bottom should occur preferentially in the Hudson channel region of the bight. A ubiquitous force for driving estuarine and coastal circulations is the horizontal pressure gradient. The horizontal pressure gradient is expressible as

$$
\frac{\partial P}{\partial l}=g\left[\rho S-\int_{0}^{d} \frac{\partial \rho}{\partial l} d z\right]
$$

where

$$
\begin{aligned}
& P \text { is pressure, } \\
& \ell \text { is horizontal direction, } \\
& g \text { is gravitational constant, } \\
& \rho \text { is density, } \\
& S \text { is surface slope, } \\
& z \text { is vertical direction, and } \\
& d \text { is a particular depth of interest. }
\end{aligned}
$$

In estuarine circulation, a near-surface seaward flow is driven by the pressure gradient associated with surface slope. At greater depths, the surface slope term is opposed by the vertically integrated horizontal gradient $\partial \rho / \partial \ell$, typically reversing it to drive a counterflow at intermediate or great depths. 


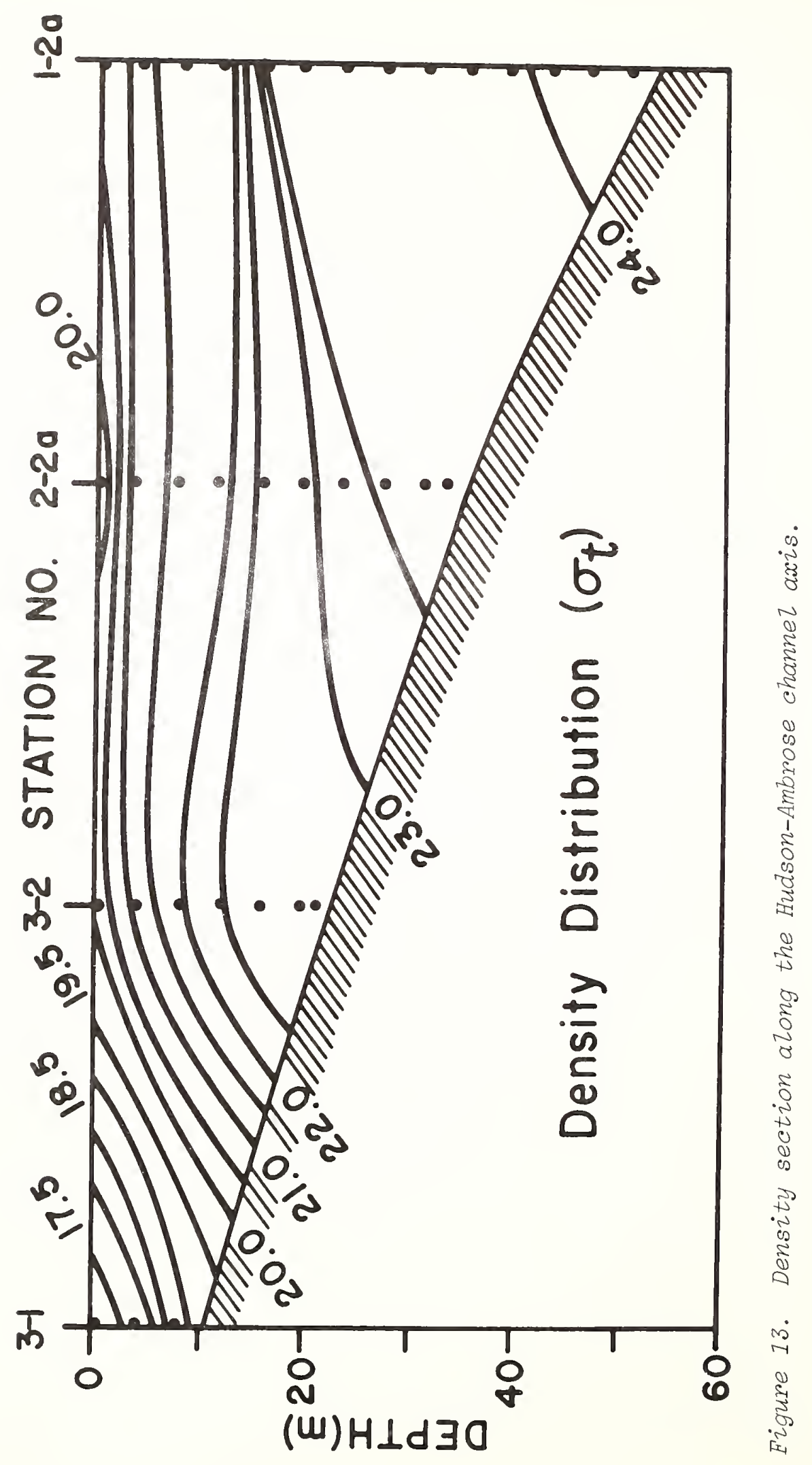


Figure 13 shows that the horizontal density gradient is significant to the greatest depths found in the region. Hence, by virtue of the fact that the Ambrose and Hudson channels have more than twice the depth of adjacent regions, we expect that the estuarine circulation, well-documented within the estuary, must preferentially occur also within the channelized portion of the New York Bight.

In a similar manner, the density distribution for the entire spring (March-June) suggests characteristic estuarine circulation--outflow at the surface accompanied by bottom return flow up the channel into the bay.

An alternative qualitative interpretation for the large-scale aspects of this observed density distribution is that it is, in part, a quasi-geostrophic response to the general clockwise circulation in the apex, having a tendency for flow toward shore in the bottom boundary layer. The difficulty of determining circulation in such coastal regions stems from the coincidence of a multiplicity of processes.

\subsection{Distribution of Deposited Organic Carbon on the Sea Floor}

There is indirect evidence in support of the pattern of bottom water movement as inferred from the seabed drifters. This evidence results from deposition of organic carbon on the sea floor in the vicinity of the dump sites. Contours of the ratio of organic carbon to total weight of bottom sample, published by Sandy Hook Laboratory (1972), are presented in figure 14. For the case of the sewage sludge dump site, the deposition plume stretches to the northeast, with diminishing concentrations away from the dump site. Sewage sludge is 


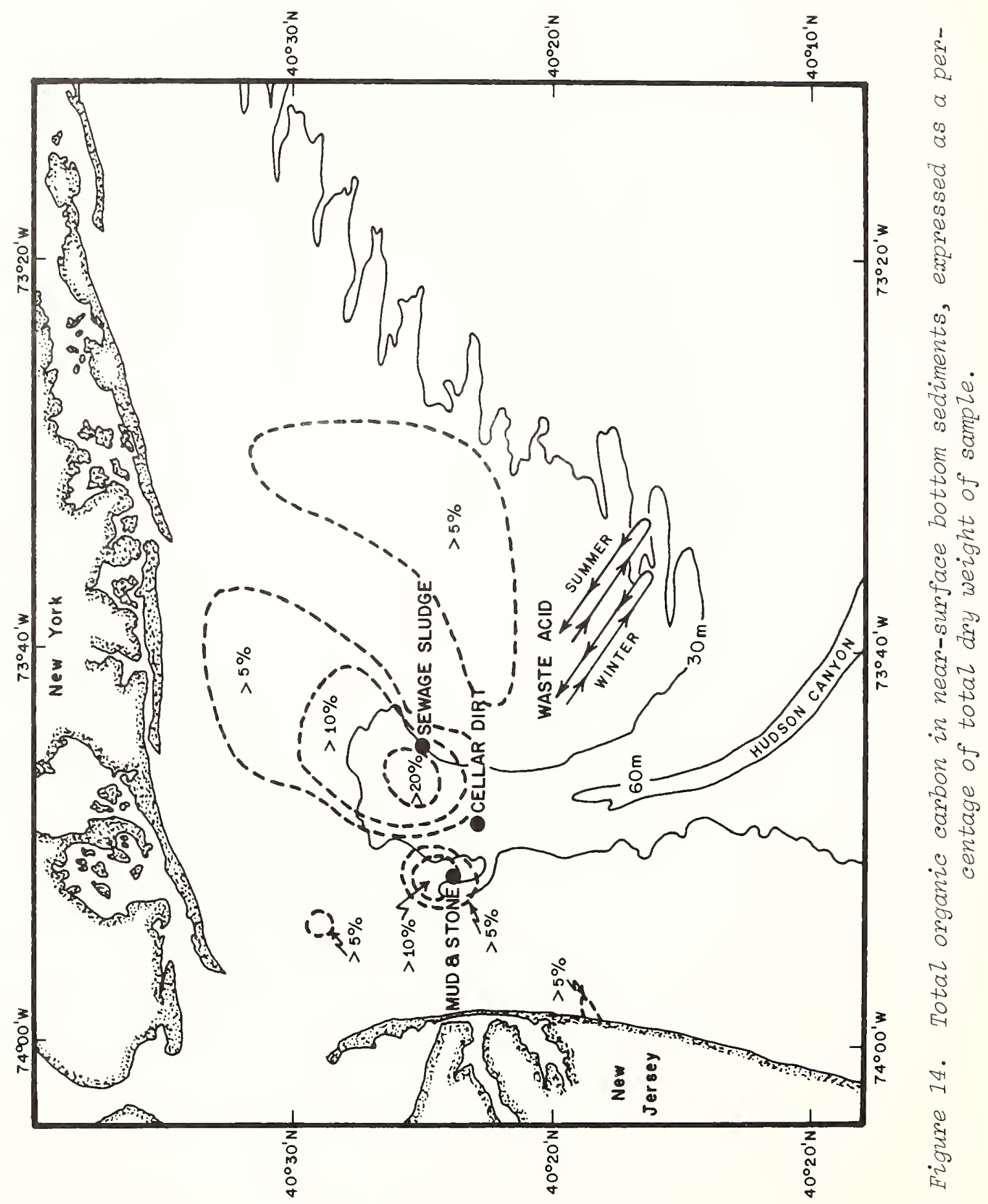


composed of particulates which take a finite amount of time to settle to the bottom. During the period of settling, suspended particulates will be transported horizontally by currents. Hence, the bottom distribution pattern should indicate the mean direction of transport. If organic carbon in bottom samples is a suitable indicator of sewage sludge spoils, then data from figure 14 indicate that mean currents between the head of the Hudson shelf channel to the coast of Long Island generally are to the northeast.

If water continues moving east as suggested by the drifters and by current meter measurements, it must eventually enter the offshore circulation system with its tendency for southwest flow. This then would form a closed circulation pattern, represented by an anticyclonic gyre encompassing most of the apex in and to the east of the Hudson shelf channel.

\section{SUMMARY}

During 1969, diverse data types were collected at monthly intervals to describe the physical oceanography in the apex of the New York Bight. Data types include temperature and salinity, return information on surface and bottom drifters, and current meter observations. The data were used to describe water structure and nearshore circulation as they relate to the dispersal of sewage sludge and dredging spoils deposited in the bight waters. Analysis of these data results in several conclusions.

(a) Water in the apex is stratified for about three-fourths of the year: firstly, caused by high river runoff in spring; then secondly, by 
solar heating throughout the summer. From November through February, heat loss and wind mixing destroy and impede reformation of stratification. Following breakdown of stratification in October, apex water rapidly loses heat through normal thermal transfer processes at the sea surface. (b) Effluent from Raritan Bay flows south along the New Jersey coast most of the year, probably caused by momentum and Coriolis force. This results in the western part of the apex being predominantly estuarine in character; however, east of the Hudson shelf channel, apex water is predominantly shelf-oceanic.

(c) There was substantial shoreward migration of drifters deposited on the surface or at the bottom. Over 29 percent of all drifters released found their way to shore. Drifter data suggest a strong northward flow at the bottom along the axis of the Hudson shelf channel and then into the mouth of the Hudson estuary. Additionally, there is a large component of this northward flow that continues north then east along the Long Island shore. Continuity considerations suggest this eastward flow must turn to the southwest as it meets the southwest-tending shelf water. This flow pattern would result in an anticyclonic circulation feature that exists in the apex during most of the year.

(d) While surface drift patterns exhibit strong seasonality, there is only mild seasonal variation in returns of bottom drifters. Surface seasonality results from change in wind structure over the apex. Dominant winds are to the north (and hence high returns on Long Island) during spring and summer. During fall and winter, winds are generally to the southeast and tend to blow floating material out to sea. 


\section{ACKNOWLEDGMENTS}

This work was supported in part by the Environmental Research Laboratories and the Marine Ecosystems Analysis Project of the National Oceanic and Atmospheric Administration.

\section{REFERENCES}

Bigelow, H. B. (1933): Studies of the waters on the continental shelf, Cape Cod to Chesapeake Bay: I. The cycle of temperature, MIT-WHOI Papers Phy. Oceanogr. Meteoro1., II (4): $135 \mathrm{pp}$.

Bigelow, H. B. and M. Sears (1935): Studies of the waters on the continental shelf, Cape Cod to Chesapeake Bay: II. Salinity, MIT-WHOI Papers Phys. Oceanogr. Meteoro1., IV(1): 94 pp.

Bumpus, D. F. (1973): A description of the circulation on the continental shelf of the east coast of the United States, Progr. Oceanogr., 6: 111-157.

Bumpus, D. F. (1965): Residual drift along the bottom on the continental shelf in the Middle Atlantic Bight area, Limnol. Oceanogr., 10 (Supp.) : R50-R53.

Bumpus, D. F., and L. M. Lauzier (1965): Surface circulation on the continental shelf off Eastern North America between Newfoundland and Florida, Serial Atlas of the Marine Environment Folio $\underline{7}$, American Geographical Society, New York, N. Y., unpaginated. Charne11, R. L., J. R. Ape1, W. Manning, III, and R. H. Qualset (1974): Utility of ERTS-I for coastal ocean observation: The New York Bight example, Marine Technol. Soc. J., 8(3): 42-47. 
Chase, J. (1971): Oceanographic observations along east coast of United

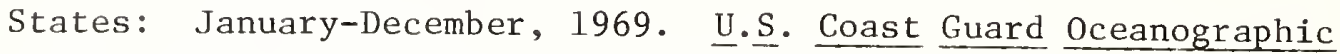
Report 非6, CG 373-46, U.S. Coast Guard Oceanographic Unit, Washington, D. C., $147 \mathrm{pp}$.

Conomos, T. J., D. H. Peterson, P. R. Carlson, and D. S. McCulloch (1970): Movement of seabed drifters in the San Francisco Bay estuary and the adjacent Pacific Ocean: A preliminary report, U.S. Geological Survey Circular 637-B, U.S. Geological Survey, Washington, D. C., B1-B8.

Gross, M. G., B. A. Morse, and C. A. Barnes (1969): Movement of nearbottom waters on the continental shelf off the Northwestern United States, J. Geophys. Res.., $74(28)$ : 7044-7047.

Harrison, W., J. J. Norcross, N. A. Pore, and E. M. Stanley (1967): Circulation of shelf waters off the Chesapeake Bight; surface and bottom drift of continental shelf waters between Cape Henlopen, Delaware, and Cape Hatteras, North Carolina, June 1963-December 1964 , $\underline{\text { ESSA Professiona1 }} \underline{\text { Paper }} \underline{\text { No. }}$ 3, U.S. Dept. of Commerce, Washington, D. C., $82 \mathrm{pp}$.

Ketchum, B. H., A. C. Redfield, and J. C. Ayers (1951): The oceanography of the New York Bight, WHOI Papers Phys. Oceanogr. Meteorol., XII(1): $4-46$.

Sandy Hook Laboratory (1972): The effects of waste disposal in the New York Bight, Summary Final Report, submitted to the U.S. Army Corps of Engineers, Coastal Engineering Research Center, National Marine Fisheries Service, Middle Atlantic Coastal Fisheries Center, Highlands, N. J., $70 \mathrm{pp}$. 
Stewart, H. B., Jr. (1958): Upstream bottom currents in New York Harbor, Science, $127(3306):$ 1113-1114.

Water Resources Division (1970): Water Resources Data for New York:

Part I. Suriace Water Records, 1969, U.S. Geological Survey, Washington, D.C., $283 \mathrm{pp}$.

Water Resources Division (1971): Water Resources Data for New York:

Part I. Surface Water Records, 1970, U.S. Geological Survey, Washington, D.C., $302 \mathrm{pp}$. 


\section{APPENDIX}

\section{Temperature}

(1) Bucket Temperature. The mercury thermometers used for measuring bucket temperature have a precision of $0.5^{\circ} \mathrm{C}$ and are calibrated to an accuracy of $\pm 0.1^{\circ} \mathrm{C}$. The temperatures obtained from bucket samples were used to check the validity of those taken with the Beckman RS-5-3 and $\mathrm{CM}^{2}$ salinometers.

(2) Electrical Resistance Thermistor. The electrical resistance thermistor is incorporated in the sensing probe of a Beckman RS-5-3 salinometer. This instrument gives temperature readings of $0.01^{\circ} \mathrm{C}$ and is accurate to $\pm 0.1^{\circ} \mathrm{C}$. The $\mathrm{RS}-5-3$ was calibrated in the laboratory and found accurate within these limits specified by the manufacturer. Its accuracy was rechecked at each sampling location by comparing surface readings with a mercury thermometer and bottom readings with a reversing thermometer attached to a Nansen bottle.

(3) Temperature Recorders. Geodyne Temperature Recorders (Model A-1194), along with the current meters referred to below, were placed at fixed locations. These instruments record temperature to an accuracy of $\pm 0.25^{\circ} \mathrm{C}$. 


\section{Currents}

(1) Currents were estimated in the study area by using surface drift bottles, seabed drifters, and permanently fixed recording current meters.

(2) Surface drift bottle and seabed drifter data were sent directly to the Woods Hole Oceanographic Institution where they were processed and entered into the computer program directed by Dean Bumpus. The results were returned to the Sandy Hook Sport Fisheries Marine Laboratory month1y.

(3) Model A-100 Woods Hole current meters were installed at fixed stations for current measurements. Current velocity and direction were recorded every one-half hour for various time periods.

(4) Current meters were pretested and calibrated in the laboratory following directions of the manufacturer.

\section{Salinity}

(1) Salinity was measured with Beckman RS-5-3 and $\mathrm{CM}^{2}$ salinometers. The RS-5-3 is a portable, battery-operated, inductively coupled instrument, giving a direct reading of salinity in parts per thousand. The accuracy of the instrument is rated at 0.3 percent for salinities in the 0 to $40 \%$ range over a temperature range of $0^{\circ}$ to $27^{\circ} \mathrm{C}$. 
(2) Accuracy of the RS-5-3 and the $\mathrm{CM}^{2}$ salinometers was checked by taking surface samples at each station with a bucket and bottom samples with a Nansen bottle and by determining the salinity of each titration, using the Harvey method. Field calibration was maintained by using a 50-ohm calibration 1oop.

\section{Dissolved Oxygen}

(1) The Alsterberg Modification of the Winkler Method was used to determine the dissolved oxygen (mg/l) in seawater collected near the bottom with a Nansen bottle. 

PENN STATE UNIVERSITY LIBRARIES

TIIII)

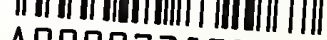

A00007283296? 